\title{
The effect of temperature on the methane yield of the slurry contaminated with heavy metals
}

\author{
Anna Smurzyńska, Wojciech Czekała*, Jacek Dach, Damian Janczak, Piotr \\ Boniecki
}

Institute of Biosystems Engineering, Poznan University of Life Sciences, ul. Wojska Polskiego 28, 60-637 Poznan, Poland

\begin{abstract}
The intensive livestock production is responsible for a number of environmental threats. The main source of animal waste is generated in the form of slurry. The inadequate fertilizing (against the BAT rules) can often lead to contamination of soil and water. In turn, the presence of heavy metals found in factory farms by the use of animal feed supplements, prevents its use as a fertilizer. Therefore, other possibilities to recycle the waste are being studied. The aim of the research was to analyze the effect of heavy metal ions on the methane fermentation process yield in contaminated slurry. The manure studied came from dairy cattle farm in Greater Poland region. The tested substrate has been contaminated by heavy metal salts. In the experiment, the following salts have been used $\mathrm{ZnO} 4 \cdot 7 \mathrm{H} 20$, $\mathrm{CdCl}_{2} \cdot 2,5 \mathrm{H}_{2} \mathrm{O}, \mathrm{CuSO} 4 \cdot 5 \mathrm{H}_{2} \mathrm{O}, \mathrm{Pb}\left(\mathrm{NO}_{3}\right)_{2}$. Anaerobic biodegradation of the fertilizer has been carried out in thermophilic conditions, which enables to indicate the effect of temperature on the efficiency of the occurring process. Furthermore, by comparing mesophilic and thermophilic fermentation, one can notice a higher methane yield from the contaminated slurry during the fermentation at lower temperatures.
\end{abstract}

Keywords: Slurry; biogas; thermophilic fermentation; mesophilic fermentation; heavy metals

\section{Introduction}

An intensive animal production carries a number of risks to the environment. This is mainly due to the resulting odor and greenhouse gas emissions [1]-[3]. It's also noted that the arising large number of animal manure require proper disposal being a source of gas emission as well as biogenic substances. Improper management can lead to soil contamination as well as surface and ground water pollution [4][6]. Herefore, animal slurry require proper disposal in accordance with the law [7].

One of the possibilities of managing animal manure on litter-free farms is methane fermentation. Anaerobic decomposition of organic substances allows obtaining a safe high yield fertilizer in form of raw slurry called a digestate [8], [9]. In addition, the resulting biomass is much safer by reducing pathogenic organisms present in the animal faeces due to the temperature at which the process occurs. An important issue in the methane fermentation process is to preserve the proper parameter values [10]. One has to have in mind the anaerobic conditions, the availability of organic matter, the presence of bacterial microflora and proper temperature. There is also a set of factors that prevent the decomposition of organic substances. In case of slurry, it relates to, inter alia, heavy metals, which in high concentration lead to a process halt. These substances are a serious threat to the environment, humans and animals [11]. The presence of heavy metals in slurry results from the application of animal feed supplements [12], [13]. These pharmaceuticals are commonly used in large-size farms, aimed at high yield of animals kept [14][16]. Rapid weight gain and protection against invasive disease of animals were possible thanks to feed supplements often used without any control, which have been banned to a large extent as a result of the

\footnotetext{
*Manuscript received November 17, 2016; revised April 10, 2017.

Corresponding author. Tel.: +98618987156; E-mail address: wojciech@up.poznan.pl.

doi: $10.12720 /$ sgce.6.2.127-132
} 
side effects observed in the environment [17]. The current situation makes it necessary to carry out tests to determine the efficiency level of slurry methane fermentation contaminated with heavy metals in the case of inability of fertilizing application. Thus, the objective of described research is to determine the content of selected heavy metals in slurry on its usefulness in the process of biogas production.

\section{Materials and Methods}

The research was conducted in the Ecotechnologies Laboratory at Poznan University of Life Sciences the largest biogas laboratory in Poland. The gas emission analysis from slurry was based on a modified German standard DIN 38 414/S8 and standardized biogas guide of the German Engineers Association in Dresden VDI 4630. Chemical analyzes were made in accordance with Polish Standards. The research methodology in the field of bio-waste was developed by means of grants carried out in the course of the 6th Framework Project of the EU and Polish Ministry of Science and Higher Education in years 20062012.

\subsection{Slurry and inoculum}

The research material was cattle slurry coming from a private farm in Greater Poland, contaminated with heavy metals. For each slurry sample the following heavy-metal salts were added:

- $\mathrm{ZnO}_{4} \cdot 7 \mathrm{H}_{2} 0$,

- $\mathrm{CdCl}_{2} \cdot 2,5 \mathrm{H}_{2} \mathrm{O}$,

- $\mathrm{CuSO}_{4} \cdot 5 \mathrm{H}_{2} 0$,

- $\mathrm{Pb}\left(\mathrm{NO}_{3}\right)_{2}$.

Also, a sample with a mixture of all heavy metal salts (mix) was created. In determining the dosage of heavy metal salts it was assumed that their concentrations in the slurry exceed the limit allowing for the fertilizer use [18], [19].

The inoculum was a liquid digestate fraction from the thermophilic reactor, operating in quasi continuous system in the Ecotechnologies Laboratory. The slurry mixtures with the inoculum were prepared in accordance with Table 1. The proportions were established on the basis of the physicochemical parameters of substrates.

Table 1. Slurry and inoculum in fermentation mixture

\begin{tabular}{cc}
\hline Substrate & Content $[\mathrm{g}]$ \\
\hline Slurry & 289 \\
Inoculum & 911 \\
\hline
\end{tabular}

Table 2. The concentration of heavy metal ions in the fermentation mixture

\begin{tabular}{c|c}
\hline Heavy metal ions, & $\begin{array}{c}\text { Content } \\
{\left[\mathrm{mg} / \mathrm{dm}^{3} \text { of dry wieght }\right]}\end{array}$ \\
\hline Zinc & 1800 \\
Cadmium & 6 \\
Copper & 480 \\
Lead & 168 \\
Mix: & \\
Zinc & 1800 \\
Cadmium & 6 \\
Copper & 480 \\
Lead & 168 \\
\hline
\end{tabular}

Table 2 includes data relating to heavy metal concentration in the fermentation mixture prepared (cattle slurry and inoculum). 


\subsection{Methane production}

Biogas efficiency tests of substrates were carried out in a multi-chamber biofermentor (Fig. 1) designed and built at the UP Institute of Biosystems Engineering in Poznań.

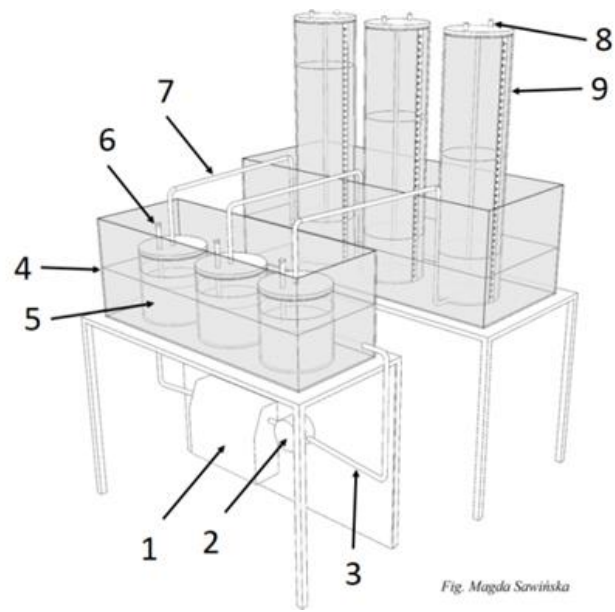

Fig. 1. Scheme of biofermentor for biogas production research (3-chamber section): 1 - water heater with temperature regulator, 2-water pump, 3-insulated conductors of calefaction liquid, 4-water coat with temp. $39^{\circ} \mathrm{C}$, 5-biofermentor with charge capacity $2 \mathrm{dm} 3,6$-sampling tubes, 7-biogas transporting tube, 8-gas sampling valve, 9-biogas volumescale reservoir.

Methane fermentation was conducted in a glass biofermentor with a capacity of $2 \mathrm{dm}^{3}$. The tested substrate was placed in a biofermentor, and then coated with a sufficient amount of inoculum. After purging the biofermentor with nitrogen (to create the anaerobic conditions) they were placed in a water bath at $55^{\circ} \mathrm{C} \pm 1$ in order to ensure optimal conditions for the process of methane fermentation in the thermophilic conditions to occur. Biogas produced in each chamber was transported via PTFE tubings to the biogas reservoir constructed with an inverted cylinder immersed in water and adding a liquid column. At water - gas interfacials there was a liquid barrier to prevent dissolution of $\mathrm{CO} 2$ in water. All sample were tested in triplicate.

\subsection{Gas samples}

The daily biogas production measurements were performed at $24 \mathrm{~h}$ intervals with an accuracy of 0.01 $\mathrm{dm}^{3}$. Qualitative and quantitative composition of fermentation gases were determined using a GA5000 gas analyzer by Geotech each time when the volume of gas in the tube exceeded $450 \mathrm{ml}$ (this was due to the analyzer demand to perform measurement). GA5000 gas analyzer had the following quality certificates: ATEX II $2 \mathrm{G}$ Ex ib IIA T1 $\mathrm{Gb}\left(\mathrm{Ta}=-10^{\circ} \mathrm{C}\right.$ do $\left.+50^{\circ} \mathrm{C}\right)$, IECEx, CSA as well as UKAS ISO 17025 calibration certificate. It allowed to take gas measurements in ranges: O2 0-25\%; CO2 0-100\%; CH4 0-100\%; NH3 0-1000 ppm and H2S 0-10 $000 \mathrm{ppm}$. Calibration of the analyzer was performed every week using a calibration gases supplied by Air Product under the following concentrations: 65\% CH4, $35 \% \mathrm{CO} 2$ (in a single mixture); $500 \mathrm{ppm} \mathrm{H} 2 \mathrm{~S}$ and $100 \mathrm{ppm} \mathrm{NH}$. Calibration of the oxygen sensor was made in synthetic air. According to the German standard DIN 38 414-S8 the criterion to complete the efficiency tests was the moment in which the daily biogas production accounted for less than $1 \%$ of the total production obtained.

\section{Results and Discussions}

For the proper functioning of the bacteria, both macro and microelements are essential, constituting one of the essential nutrients [20]. The presence of heavy metals is a major barrier to the methane production. Many studies emphasize an inhibitory effect or a significant reduction of methane 
fermentation yield by the increased concentrations of heavy metals on methane fermentation process [21][23]. The reduction of methane in case of slurry containing copper, zinc, cadmium and lead have also been noticed in the performed experiment. Another confirmation of the negative impact of heavy metals is the fact of obtaining the highest efficiency of biogas and methane from pure manure.

Table 3. Methane and biogas efficiency of the tested slurry subjected to thermophilic fermentation

\begin{tabular}{ccc}
\hline Sample & $\begin{array}{c}\text { Cumulated methane } \\
{\left[\mathrm{m}^{3} \cdot \mathrm{Mg}^{-1} \mathrm{VS}\right]}\end{array}$ & $\begin{array}{c}\text { Cumulated biogas } \\
{\left[\mathrm{m}^{3} \mathrm{Mg}^{-1} \mathrm{VS}\right]}\end{array}$ \\
\hline Slurry & 400.49 & 625.97 \\
Slurry + Zn & 258.19 & 394.76 \\
Slurry + Cd & 259.07 & 403.17 \\
Slurry + Cu & 220.89 & 334.54 \\
Slurry + Pb & 267.40 & 409.06 \\
Slurry + mix & 247.58 & 393.94 \\
\hline
\end{tabular}

It is noted as given in Table 3, that the least affected salts on the biogas and methane efficiency of slurry are cadmium and lead. It should be emphesized, however, that the concentration of these metals is lower in comparison to other heavy metals used in the experiment. The lowest biogas and methane yield is observed for the slurry containing copper and zinc ions and all salts (mix). This is alarming as copper is a basic component of feed supplements having a bactericide nature, very often used in farm animal breeding [24]. On the other hand, zinc is responsible for the functioning of the immune system [25].

The carried out tests in the Environmental Technologies Laboratory have also been carried out for methane fermentation process, however, in mesophilic conditions. These data were published in the journal Episteme no. 30/2016, t. 1 in an article entitled "The impact of the increased concentration of lead, cadmium, zinc and copper ions in the methane fermentation slurry." It is noted that the presence of heavy metals greatly reduce the yield of methane and biogas fermentation mixture, especially in thermophilic conditions.

Table 4. The level of methane yield reduction in both mesophilic and thermophilic fermentation of slurry contaminated with heavy metals

\begin{tabular}{lcc}
\hline Sample & $\begin{array}{c}\text { mesophilic } \\
\text { fermentation [p.p.] }\end{array}$ & $\begin{array}{c}\text { thermophilic } \\
\text { fermentation [p.p.] }\end{array}$ \\
\hline Slurry + Zn & -19.46 & -35.53 \\
Slurry + Cd & -14.09 & -35.31 \\
Slurry + Cu & -19.23 & -44.85 \\
Slurry + Pb & -14.76 & -33.23 \\
Slurry + mix & -31.55 & -38.18 \\
\hline
\end{tabular}

Reduction in methane yield reaches the level from 33.23 to 44.85 p. p. in case of thermophilic fermentation, while below the decomposition temperature the reduction of process yield is in the range of 14.09 to 31.55 p.p. (Table 4) The significant difference of the methane yield between the mesophilic and thermophilic fermentation arises from the reaction of microorganism, present in the manure, on the temperature. The fermented slurry in thermophilic conditions has a lower efficiency due to the lack of the bacterial microflora, capable of functioning at high temperature.

Therefore, it should be emphasized that such a large efficiency decrease in the ongoing process leads to a significant reduction in the profitability of recycling the contaminated slurry by methane fermentation.

\section{Conclusions}

Heavy metals significantly reduce the efficiency of the methane fermentation in the thermophilic conditions. The heavy metal ions influencing biogas and methane yield on contaminated slurry at 
thermophilic fermentation are the following: $\mathrm{Cu}>\operatorname{mix}>\mathrm{Zn}>\mathrm{Cd}>\mathrm{Pb}$. It can be observed that there is a lower methane fermentation yield of the contaminated slurry by heavy metals in thermophilic conditions compared to fermentation under mesophilic conditions.

\section{References}

[1] Häni C, Sintermann J, Kupper T, Jocher M, Neftel A. Ammonia emission after slurry application to grassland in Switzerland. Atmospheric Environment, 2016; 125:92-99.

[2] Regueiro I, Coutinho J, Fangueiro D. Alternatives to sulfuric acid for slurry acidification: impact on slurry composition and ammonia emissions during storage. Journal of Cleaner Production, 2016; 131:296-307.

[3] Smurzyńska A, Dach J, Czekała W. Technologies to reduce emissions of noxious gases resulting from livestock farming. Ecological Engineering, 2016a; 47:189-198.

[4] Wang RL, Liang JG, Lu L, Zhang LY, Li SF, Luo XG. Effect of zinc source on performance, zinc status, immune response, and rumen fermentation of lactating cows. Biological Trace Element Research, 2013; 152:16-24.

[5] Dach J, Koszela K, Boniecki P, Zaborowicz M, Lewicki A, Czekała W, Skwarcz J, Wei Q, Piekarska BH, Białobrzewski I. The use of neural modelling to estimate the methane production from slurry fermentation processes. Renewable and Sustainable Energy Reviews, 2016; 56:603-610.

[6] Müller C, Laughlin RJ, Christie P, Watson CJ. Effects of repeated fertilizer and cattle slurry applications over 38 years on N dynamics in a temperate grassland soil. Soil Biology and Biochemistry, 2011; 43(6):1362-1371.

[7] Smurzyńska A, Dach J, Dworecki Z, Czekała W. Gas emissions during slurry management. Engineering and Protection of Environment, 2016; 19:109-125.

[8] Czekała W, Bartnikowska S, Lewicka A, Bugała A, Zbytek Z, Lewicki A. Economic and energy efficiency of the solid biofuels produced from digested pulp. In: Proc. of MATEC Web of Conferences, 2016.

[9] Czekała W, Dach J, Przybył J, Boniecki P, Lewicki A, Carmona PCR, Janczak D, Waliszewska H. The energetic efficiency of solid fraction of digestate pulp from biogas plant in production of solid and gaseous biofuels-a case study of 1 MWel biogas plant in Poland. In: Proc. of 2nd International Conference on Energy \& Environment: Bringing Together Engineering and Economics, 2015:547-553

[10] Czekała W, Kozłowski K, Dach J, Boniecki P, Lewicki A, Janczak D, Jóźwiakowski K, Piechota T. Energy conversion from biomass to hydrogen and methane. In: Proc. of 4th International Conference on Materials Engineering for Advanced Technologies (ICMEAT) Location: London, England, 2015:654-657.

[11] Neugebauer M, Sołowiej P, Piechocki J. Fuzzy control for the process of heat removal during the composting of agricultural waste. J. Mater Cycles Waste Manag, 2014; 16:291-297.

[12] Nicholsona FA, Chambersa BJ, Williamsb JR, Unwinc RJ. Heavy metal contents of livestock feeds and animal manures in England and Wales. Bioresource Technology, 1999; 70:23-31.

[13] Huaynate RAR., Thomaz MC., Kronka RN., Fraga AL., Scandolera AJ., Budiño FEL. Effect of adding macro and micro minerals in pig feces fed diets with different levels of probiotic. Brazil. Arch. Biol. Technol, 2016; 49:385-392.

[14] Wang Q, Cui Y, Liu X, Dong Y, Christie P. Soil contamination and plant uptake of heavy metals at polluted sites in China, Journ. Environ. Sci. Health Part A, 2003; 38:823-838.

[15] Cope CM, Mackenzie AM, Wilde D, Sinclair LA. Effects of level and form of dietary zinc on dairy cow performance and health. J. Dairy Sci., 2009; 92:2128-2135.

[16] Enjalbert F, Lebreton P, Salat O. Effects of copper, zinc and selenium status on performance and health in commercial dairy and beef herds: Retrospective study. J. Anim. Physiol. Anim. Nutr. (Berl), 2006; 90:459-466.

[17] Li Y, McCrory DF, Powell JM, Saam H, Jackson SD. A survey of selected heavy metal concentrations in Wisconsin dairy feeds. J. Dairy Sci., 2005; 88:2911-2922.

[18] Ustawa z dnia 10 lipca 2007 r. o nawozach i nawożeniu.

[19] Rozporządzenie Ministra Rolnictwa i Rozwoju Wsi z dnia 18 czerwca 2008 r. w prawie wykonania niektórych przepisów ustawy o nawozach i nawożeniach.

[20] Talarowska A, Niemiałkowska BI, Sokołowska Z, Boguta P. The carbon content and the metal cations in the selected organic wastes for their use in the production of biogas. Acta Agrophysica, 2011; 18(1):161-172.

[21] Abdel SHI, Mansourb MSM. Biogas production as affected by heavy metals in the anaerobic digestion of sludge. Egyptian Journal of Petroleum, 2014; 23(4):409-417.

[22] Yu HQ, Fang HHP. Inhibition by chromium and cadmium of anaerobic acidogenesis. Water Science and Technology, 2011; 43(11):267-274.

[23] Yenigun O, Kizilgun F, Yilmazer G. Inhibition effects of zinc and copper on volatile fatty acid production during anaerobic digestion. Environ. Tech., 1996; 17(12):1269-1274. 
[24] Włodarczyk R, Geier U. Efektywność wykorzystania mikroelementów w zależności od postaci ich podaży w żywieniu świń. Życie Weterynaryjne, 2010; 85(7):594-97.

[25] Grela ER, Pastuszak J. Żywieniowe i profilaktyczne znaczenie cynku w chowie świń. Medycyna Weterynaryjna,. 2004; 60:1254-1258. 